\title{
In-Hospital Mortality After Blood Purification With and Without Acrylonitrile-Co-Methallyl Sulfonate Surface-Treated Membrane for Pneumonia- Associated Sepsis: A Retrospective Cohort Study
}

Kentaro Hayashi ( $\nabla$ kentarou@dokkyomed.ac.jp )

Dokkyo medical university https://orcid.org/0000-0003-0775-9821

Yusuke Sasabuchi

Jichi Medical University: Jichi Ika Daigaku

Hiroki Matsui

Tokyo Daigaku - Komaba Campus

Mikio Nakajima

Tokyo Metropolitan Hiroo Hospital: Tokyo Toritsu Hiroo Byoin

Hiroyuki Ohbe

Tokyo Daigaku - Komaba Campus

Kiyohide Fushimi

Tokyo Ika Shika Daigaku

Kazuyuki Ono

Dokkyo Medical University: Dokkyo Ika Daigaku

Hideo Yasunaga

Tokyo Daigaku - Komaba Campus

Research

Keywords: Continuous renal replacement therapy, AN69ST membrane, cytokine adsorption therapy, pneumonia, sepsis

Posted Date: September 22nd, 2020

DOI: https://doi.org/10.21203/rs.3.rs-74891/v1

License: (9) (1) This work is licensed under a Creative Commons Attribution 4.0 International License. Read Full License 


\section{Abstract}

Background: Cytokine removal therapy is one of the available therapies for sepsis. Acrylonitrile-comethallyl sulfonate surface-treated (AN69ST, sepXiris ${ }^{\circledR}$ ) membrane has cytokine adsorption capacity and has been widely used for treating sepsis in Japan. The aim of this study was to compare the effects of continuous renal replacement therapy (CRRT) with AN69ST membrane and conventional CRRT for patients with pneumonia-associated sepsis.

Methods: We conducted a retrospective cohort study using the Diagnosis Procedure Combination database, a nationwide inpatient database in Japan. We identified adult patients who were hospitalized due to pneumonia and received CRRT within 2 days of admission from September 2014 to March 2017. We included patients who received CRRT with AN69ST membrane within 2 days of admission in the treatment group (AN69ST group); those who received CRRT with other membranes within 2 days of admission were included in the control group (non-AN69ST group). Propensity score matching was used to compare in-hospital mortality between the two groups.

Results: Eligible patients $(n=2,393)$ were categorized into the AN69ST group $(n=631)$ or the non-AN69ST group $(n=1,762)$. The overall in-hospital mortality rate in pneumonia patients treated with CRRT was $38.9 \%$. Propensity score matching created a matched cohort of 545 pairs of patients. The in-hospital mortality rate was significantly lower in the AN69ST group than in the non-AN69ST group (35.8 vs. 41.8\%, $p=0.046)$.

Conclusion: Our data suggest that CRRT with the AN69ST membrane was associated with a significantly lower in-hospital mortality than CRRT with standard membranes among patients with pneumoniaassociated sepsis.

\section{Background}

Sepsis causes dysfunction of various organs and death in critically ill patients [1,2]. Pneumonia is the most common cause of sepsis and death worldwide [3-5]. Cytokines possibly have an essential role in the mechanism of organ dysfunction and mortality due to sepsis [6, 7].

Although continuous renal replacement therapy (CRRT) removes cytokines and other mediators [8], it does not improve clinical outcomes regardless of the applied dose [9-14]. In recent years, various new approaches regarding CRRT treatments, such as endotoxin adsorption therapy using polymyxin B hemoperfusion (PMX-DHP) [15-17] and cytokine removal therapy using standard CRRT membranes [18, $19]$, have been introduced to improve the prognosis of sepsis with hypercytokinemia [20,21].

Acrylonitrile-co-methallyl sulfonate surface-treated (AN69ST) membrane is one of the membranes used for CRRT and is introduced for cytokine adsorption therapy in Japan since September 2014. The AN69ST membrane has a hydrogel structure, which enables cytokine adsorption not only in the membrane surface but also within the bulk layer, thereby exhibiting an increased capacity for cytokine removal in vitro [22- 
25]. Therefore, the standard CRRT membrane has been widely replaced by the AN69ST membrane to absorb cytokines in critically ill patients in Japan, regardless of the cause of sepsis. However, only a few clinical studies [26-30] on the AN69ST membrane have been reported, and the clinical effectiveness of the AN69ST membrane is still unclear.

Thus, the aim of our present study is to investigate the clinical effect of the AN69ST membrane compared with those of standard CRRT membranes in patients with pneumonia-associated sepsis.

\section{Materials And Methods}

\section{Study design and data source}

For this retrospective cohort study, we used the Japanese Diagnosis Procedure Combination Database [31]. This database contains administrative claims data and clinical information. All 82 academic hospitals are obliged to provide information to this database. However, participation by community hospitals is voluntary. The database includes the following information: age, sex, diagnosis (primary diagnosis at admission, comorbidities at diagnosis, and post-admission complications) recorded by the International Classification of Diseases, 10 th Revision (ICD-10) codes [32,33] as well as the following text data in Japanese, whether transferred by ambulance, medical procedures including types of surgery, daily records of drug administration and devices used, date of admission and discharge, and discharge status. The database was structured explicitly to differentiate between pre-admission comorbidities and postadmission complications. The dates of surgery, procedures performed, and drugs administered were also recorded. All clinical data for each patient were recorded at discharge by attending physicians.

This study was approved by the Institutional Review Board of the University of Tokyo. The need for informed consent was waived because this was a retrospective study that used anonymized data.

\section{Patient selection}

We identified patients in the database with pneumonia as the primary diagnosis upon admission, and a hospital discharge date between 1 September 2014, to 31 March 2017. We included patients with pneumonia-associated sepsis according to the following criteria: (i) a primary diagnosis of pneumonia on admission (i.e. coded as pneumonia in the database; excluding suspected cases) and (ii) underwent CRRT with the AN69ST membrane or a standard membrane within 2 days of admission. The exclusion criteria were as follows: (i) age younger than 18 years; (ii) death within 2 days of admission and (iii) administration of CRRT with AN69ST membrane and a standard membrane within 2 days of admission.

\section{Exposure and endpoint}

The exposure of interest was AN69ST-CRRT (AN69ST group) compared to standard CRRT (non-AN69ST group) within 2 days at admission. The primary outcome was in-hospital mortality; the 30-day mortality rate and the length of stay were secondary outcomes. 


\section{Other variables}

Hospital volume was defined as the average annual number of pneumonia patients who have underwent any CRRT within 2 days of admission. Comorbidities on admission were extracted for each component of the Charlson Comorbidity Index, using algorithms developed by Quan et al [34]. Data were extracted from the ICD-10 codes of complications and the procedures listed in Additional File 1. Data on body weight and height were missing for some patients; thus, for these patients, body mass index values were missing.

\section{Statistical analysis}

We used propensity score methods, which have been used in several previous retrospective observational studies for comparing groups with similar characteristics without specification of the relationship between confounders and outcomes [35,36]. Similarly, we used propensity score matching [37] to adjust for differences in baseline characteristics and the severity of the condition on admission, between the AN69ST and non-AN69ST groups. To estimate the probability of receiving AN69ST-CRRT or other standard CRRT, a propensity score was calculated for each patient using multivariable logistic regression analysis. Baseline characteristics were included in the model as independent variables. All patients in the AN69ST group were 1-to-1 matched with patients in the non-AN69ST group, based on nearest-neighbor matching without replacement. The caliper was set at 0.2 for the standard deviation of the propensity scores. The balance between the two groups was compared using the standardized mean difference (SMD), and SMD less than 0.1 was considered to indicate negligible imbalance. The outcomes between the two groups were compared using Fisher's exact test for in-hospital mortality and the Mann-Whitney $U$ test for length of stay. Kaplan-Meier survival curves were plotted for the AN69ST group and the nonAN69ST group, and the log-rank test was used to compare the survival curves.

We conducted subgroup analyses on all baseline characteristics and in-hospital mortality using the Breslow-Day test for categorical variables and generalized linear models for continuous variables. A $p$ value of less than 0.05 was considered statistically significant. All analyses were conducted using SPSS version 22 (IBM Corp, Armonk, NY, US) and R version 3.1.3 (The R Foundation, Vienna, Austria).

\section{Results}

\section{Patients}

A total of 2,393 patients were included in the present study (Fig. 1), of which 631 were assigned to the AN69ST group and 1,762 were assigned to the non-AN69ST group. Table 1 shows the characteristics of the patients before and after propensity score matching. After propensity score matching, the baseline patient characteristics were well balanced between the two groups. 
Table 1

Baseline patient characteristics before and after propensity score matching

Pre-matching cohort

Propensity score matching cohort

\begin{tabular}{lllllll} 
Variable & $\begin{array}{l}\text { Non-AN69ST } \\
\text { group }\end{array}$ & $\begin{array}{l}\text { AN69ST } \\
\text { group }\end{array}$ & SMD & $\begin{array}{l}\text { Non-AN69ST } \\
\text { group }\end{array}$ & $\begin{array}{l}\text { AN69ST } \\
\text { group }\end{array}$ & SMD \\
& $(n=1762)$ & $(n=631)$ & & $(n=545)$ & $(n=545)$ \\
\hline
\end{tabular}

Fiscal year, $\mathrm{n}(\%)$

0.57

0.03

$\begin{array}{lllll}2014 & 501(28.4) & 64(10.1) & 70(12.8) & 62(11.4) \\ 2015 & 684(38.8) & 217(34.4) & 177(32.5) & \begin{array}{l}203 \\ (37.2)\end{array} \\ 2016 & 577(32.7) & 350(55.5) & 298(54.7) & \begin{array}{l}280 \\ (51.4)\end{array}\end{array}$

$\begin{array}{lllllll}\text { Age, years, mean(sd) } & 72.61(12.4) & 73.27 & 0.05 & 72.75(12.1) & 73.30 & 0.04 \\ & & (12.5) & & & (12.6) & \end{array}$

Sex, female, $\mathrm{n}(\%)$

$654(37.1) \quad 228(36.1) \quad 0.02 \quad 198(36.3)$

201

(36.9)

0.01

$\operatorname{BMI}\left(\mathrm{kg} / \mathrm{m}^{2}\right)$

0.11

0.04

$<18.5$

$348(19.8)$

$122(19.3)$

99 (18.2)

102

(18.7)

$18.5-22.5$

651 (36.9)

$230(36.5)$

$208(38.2)$

203

(37.2)

$22.5-25$

$301(17.1)$

106 (16.8)

96 (17.6)

94 (17.2)

25-30

235 (13.3)

105 (16.6)

84 (15.4)

86 (15.8)

$\geq 30$

67 (3.8)

18 (2.9)

$16(2.9)$

14 (2.6)

Missing

$160(9.1)$

$50(7.9)$

$42(7.7)$

$46(8.4)$

Transferred by

ambulance, $\mathrm{n}(\%)$

1319 (74.9)

$490(78.0) \quad 0.07 \quad 428(78.5)$

413

(75.8)

Hospital

type(academic), n (\%)

$544(30.9)$

$179(28.4)$

$0.06 \quad 168(30.8)$

158

(29.0)

Hospital volume, mean (sd)

$4.25(3.5)$

$7.07(6.7)$

0.53

$5.40(4.7)$

$5.34(5.0)$ 0.07

0.04

Type of Unit

Abbreviations: AN69ST, AN69 surface treatment; AKI, acute kidney injury; DIC, disseminated intravascular coagulation; SMD, Standardized mean difference; SD, standard deviation; BMI, body mass index; ICU, intensive care unit; HCU, high care unit; PMX-DHP, Polymyxin B-immobilized fiber column-direct hemoperfusion: Data are presented as numbers (\%) unless otherwise stated. 


\begin{tabular}{|c|c|c|c|c|c|c|}
\hline \multirow[b]{2}{*}{ ICU, n (\%) } & \multicolumn{3}{|c|}{ Pre-matching cohort } & \multicolumn{3}{|c|}{ Propensity score matching cohort } \\
\hline & $846(48.0)$ & $311(49.3)$ & 0.03 & $260(47.7)$ & $\begin{array}{l}251 \\
(46.1)\end{array}$ & 0.03 \\
\hline HCU, n (\%) & $119(6.8)$ & $35(5.5)$ & 0.05 & $34(6.2)$ & $34(6.2)$ & $\begin{array}{l}< \\
0.01\end{array}$ \\
\hline \multicolumn{7}{|l|}{ Comorbidity, n (\%) } \\
\hline Liver disease & $90(5.1)$ & $32(5.1)$ & $\begin{array}{l}< \\
0.01\end{array}$ & $29(5.3)$ & $25(4.6)$ & 0.03 \\
\hline Renal & $492(27.9)$ & $123(19.5)$ & 0.2 & $122(22.4)$ & $\begin{array}{l}117 \\
(21.5)\end{array}$ & 0.02 \\
\hline Myocardial infarction & $34(1.9)$ & $5(0.8)$ & 0.1 & $4(0.7)$ & $4(0.7)$ & $<0.01$ \\
\hline $\begin{array}{l}\text { Congestive heart } \\
\text { failure }\end{array}$ & $225(12.8)$ & $75(11.9)$ & 0.03 & $70(12.8)$ & $61(11.2)$ & 0.05 \\
\hline $\begin{array}{l}\text { Peripheral vascular } \\
\text { disease }\end{array}$ & $30(1.7)$ & $13(2.1)$ & 0.03 & $7(1.3)$ & $8(1.5)$ & 0.02 \\
\hline $\begin{array}{l}\text { Cerebrovascular } \\
\text { disease }\end{array}$ & $66(3.7)$ & $28(4.4)$ & 0.04 & $20(3.7)$ & $20(3.7)$ & $\begin{array}{l}< \\
0.01\end{array}$ \\
\hline HemiParaplegia & $2(0.1)$ & $0(0.0)$ & 0.05 & $0(0.0)$ & $0(0.0)$ & $<.01$ \\
\hline Dementia & $39(2.2)$ & $19(3.0)$ & 0.05 & $16(2.9)$ & $17(3.1)$ & 0.01 \\
\hline $\begin{array}{l}\text { Chronic pulmonary } \\
\text { disease }\end{array}$ & $44(2.5)$ & $20(3.2)$ & 0.04 & $16(2.9)$ & $18(3.3)$ & 0.02 \\
\hline Rheumatic disease & $39(2.2)$ & $14(2.2)$ & $\dot{C}_{0.01}$ & $13(2.4)$ & $13(2.4)$ & $\begin{array}{l}< \\
0.01\end{array}$ \\
\hline Peptic ulcer & $153(8.7)$ & $57(9.0)$ & 0.01 & $45(8.3)$ & $40(7.3)$ & 0.03 \\
\hline $\begin{array}{l}\text { DM without } \\
\text { complication }\end{array}$ & $162(9.2)$ & $62(9.8)$ & 0.02 & $54(9.9)$ & $50(9.2)$ & 0.03 \\
\hline DM with complication & $90(5.1)$ & $23(3.6)$ & 0.07 & $21(3.9)$ & $20(3.7)$ & 0.01 \\
\hline AIDS & $1(0.1)$ & $0(0.0)$ & 0.03 & $0(0.0)$ & $0(0.0)$ & $<0.01$ \\
\hline Malignancy & $199(11.3)$ & $78(12.4)$ & 0.03 & $56(10.3)$ & 65 (11.9) & 0.05 \\
\hline Metastatic cancer & $23(1.3)$ & $12(1.9)$ & 0.05 & $13(2.4)$ & $9(1.7)$ & 0.05 \\
\hline $\begin{array}{l}\text { Abbreviations: AN69ST, } \\
\text { intravascular coagulati } \\
\text { mass index; ICU, intensi } \\
\text { column-direct hemoperf }\end{array}$ & $\begin{array}{l}69 \text { surfac } \\
\text { SMD, Stan } \\
\text { care unit; } \vdash \\
\text { on : Data }\end{array}$ & $\begin{array}{l}\text { ent; AKI, } \\
\text { d mean d } \\
\text { h care un } \\
\text { ented as }\end{array}$ & $\begin{array}{l}\text { kid } \\
\text { ence } \\
\text { hX-[ } \\
\text { oers }\end{array}$ & $\begin{array}{l}\text { injury; DIC } \\
\text { D, standard } \\
\text { Polymyxi } \\
\text { ) unless ot }\end{array}$ & $\begin{array}{l}\text { minated } \\
\text { tion; BMI, b } \\
\text { mobilized fi } \\
\text { e stated. }\end{array}$ & \\
\hline
\end{tabular}


Blood transfusion, $\mathrm{n}$

(\%)

\begin{tabular}{lcccclc} 
Red blood cells & $722(41.0)$ & $302(47.9)$ & 0.14 & $254(46.6)$ & $\begin{array}{l}244 \\
(44.8)\end{array}$ & 0.04 \\
\hline Fresh frozen plasma & $646(36.7)$ & $279(44.2)$ & 0.15 & $232(42.6)$ & $\begin{array}{l}236 \\
(43.3)\end{array}$ & 0.02 \\
Platelet & $221(12.5)$ & $71(11.3)$ & 0.04 & $60(11.0)$ & $59(10.8)$ & $<$ \\
& & & & & & 0.01
\end{tabular}

Catecholamine, n (\%)

Dopamine

$582(33.0)$

$174(27.6)$

$0.12 \quad 143(26.2)$

154

(28.3)

Dobutamine

267 (15.2)

$114(18.1)$

$0.08 \quad 112(20.6)$

104

(19.1)

Noradrenaline

$1314(74.6)$

551 (87.3)

$0.33463(85.0)$

472

(86.6)

Adrenaline

204 (11.6)

$100(15.8)$

$0.1273(13.4)$

83 (15.2)

0.05

Vasopressin

329 (18.7)

164 (26.0)

$0.18130(23.9)$

120

(22.0)

Milrinone

$21(1.2)$

7 (1.1)

<. $01 \quad 5(0.9)$

$6(1.1)$

0.02

Oral catecholamine

23 (1.3)

$4(0.6)$

$0.07 \quad 3(0.6)$

$4(0.7)$

0.02

Intervention, $\mathrm{n}(\%)$

\begin{tabular}{|c|c|c|c|c|c|c|}
\hline $\begin{array}{l}\text { Co-administered DIC } \\
\text { drug }\end{array}$ & $1614(91.6)$ & $591(93.7)$ & 0.08 & $504(92.5)$ & $\begin{array}{l}510 \\
(93.6)\end{array}$ & 0.04 \\
\hline Immunoglobulin & $689(39.1)$ & $249(39.5)$ & $\begin{array}{l}<.01 \\
0.01\end{array}$ & $229(42.0)$ & $\begin{array}{l}231 \\
(42.4)\end{array}$ & $\begin{array}{l}< \\
0.01\end{array}$ \\
\hline Steroid by oral & $25(1.4)$ & $5(0.8)$ & 0.06 & $3(0.6)$ & $4(0.7)$ & 0.02 \\
\hline Steroid by intravenous & $701(39.8)$ & $271(42.9)$ & 0.06 & $242(44.4)$ & $\begin{array}{l}243 \\
(44.6)\end{array}$ & $\begin{array}{l}< \\
0.01\end{array}$ \\
\hline Mechanical ventilation & $1360(77.2)$ & $514(81.5)$ & 0.11 & $458(84.0)$ & $\begin{array}{l}444 \\
(81.5)\end{array}$ & 0.07 \\
\hline
\end{tabular}

Abbreviations: AN69ST, AN69 surface treatment; AKI, acute kidney injury; DIC, disseminated intravascular coagulation; SMD, Standardized mean difference; SD, standard deviation; BMI, body mass index; ICU, intensive care unit; HCU, high care unit; PMX-DHP, Polymyxin B-immobilized fiber column-direct hemoperfusion : Data are presented as numbers (\%) unless otherwise stated. 


\begin{tabular}{|c|c|c|c|c|c|c|}
\hline \multirow[b]{2}{*}{ PMX-DHP } & \multicolumn{3}{|c|}{ Pre-matching cohort } & \multicolumn{3}{|c|}{ Propensity score matching cohort } \\
\hline & $766(43.5)$ & $274(43.4)$ & $<.01$ & $243(44.6)$ & $\begin{array}{l}247 \\
(45.3)\end{array}$ & 0.02 \\
\hline Hemodialysis & $53(3.0)$ & $14(2.2)$ & 0.05 & $14(2.6)$ & $13(2.4)$ & 0.01 \\
\hline \multicolumn{7}{|l|}{ Complications, n (\%) } \\
\hline AKI after admission & $389(22.1)$ & $177(28.1)$ & 0.14 & $138(25.3)$ & $\begin{array}{l}143 \\
(26.2)\end{array}$ & 0.02 \\
\hline $\begin{array}{l}\text { Cardiovascular at } \\
\text { admission }\end{array}$ & $165(9.4)$ & $74(11.7)$ & 0.08 & $66(12.1)$ & $65(11.9)$ & $\begin{array}{l}< \\
0.01\end{array}$ \\
\hline $\begin{array}{l}\text { Neurologic at } \\
\text { admission }\end{array}$ & $12(0.7)$ & $2(0.3)$ & 0.05 & $0(0.0)$ & $1(0.2)$ & 0.06 \\
\hline $\begin{array}{l}\text { Hemotologic at } \\
\text { admission }\end{array}$ & $349(19.8)$ & $139(22.0)$ & 0.06 & $122(22.4)$ & $\begin{array}{l}123 \\
(22.6)\end{array}$ & $\begin{array}{l}< \\
0.01\end{array}$ \\
\hline Hepatic at admission & $14(0.8)$ & $5(0.8)$ & $<.01$ & $2(0.4)$ & $4(0.7)$ & 0.05 \\
\hline $\begin{array}{l}\text { Renal complication at } \\
\text { admission }\end{array}$ & $436(24.7)$ & $173(27.4)$ & 0.06 & $141(25.9)$ & $\begin{array}{l}139 \\
(25.5)\end{array}$ & $\begin{array}{l}< \\
0.01\end{array}$ \\
\hline \multicolumn{7}{|c|}{$\begin{array}{l}\text { Abbreviations: AN69ST, AN69 surface treatment; AKI, acute kidney injury; DIC, disseminated } \\
\text { intravascular coagulation; SMD, Standardized mean difference; SD, standard deviation; BMI, body } \\
\text { mass index; ICU, intensive care unit; HCU, high care unit; PMX-DHP, Polymyxin B-immobilized fiber } \\
\text { column-direct hemoperfusion : Data are presented as numbers (\%) unless otherwise stated. }\end{array}$} \\
\hline
\end{tabular}

\section{Endpoint}

The overall in-hospital mortality in this study was 38.9\% (930/2393). Table 2 shows the outcomes before and after propensity score matching. There was a significant difference in in-hospital mortality between the AN69ST group and the non-AN69ST group after propensity score matching (35.8\% vs. $41.8 \%, p=$ 0.046). Figure 2 shows the Kaplan-Meier survival curve for 30-day mortality rate of the two groups after propensity score matching. Given in the data, the 30-day mortality was significantly different between the AN69ST group and the non-AN69ST group (log-rank test, $p=0.016)$. There was also a significant difference in the length of stay between the two groups after propensity score matching ( 42.2 days and 40.0 days for the AN69ST group and the non-AN69ST group, respectively, $p=0.025$ ). 
Table 2

Outcomes before and after propensity score matching

Pre-matching cohort

\begin{tabular}{|c|c|c|c|c|c|}
\hline $\begin{array}{l}\text { Non-AN69ST } \\
\text { group }\end{array}$ & $\begin{array}{l}\text { AN69ST } \\
\text { group }\end{array}$ & $\begin{array}{l}p \\
\text { value }\end{array}$ & $\begin{array}{l}\text { Non-AN69ST } \\
\text { group }\end{array}$ & $\begin{array}{l}\text { AN69ST } \\
\text { group }\end{array}$ & $\begin{array}{l}p \\
\text { value }\end{array}$ \\
\hline$(n=1762)$ & $(n=631)$ & & $(n=545)$ & $(n=545)$ & \\
\hline 700 (39.7) & $\begin{array}{l}230 \\
(36.5)\end{array}$ & 0.161 & $228(41.8)$ & $\begin{array}{l}195 \\
(35.8)\end{array}$ & 0.046 \\
\hline $40.0(41.3)$ & $\begin{array}{l}42.2 \\
(41.8)\end{array}$ & 0.247 & $37.5(36.1)$ & $\begin{array}{l}42.9 \\
(43.3)\end{array}$ & 0.025 \\
\hline
\end{tabular}

Abbreviations: AN69ST, acrylonitrile-co-methallyl sulfonate surface-treated; SD, standard deviation

\section{Subgroup analysis}

Table 3 shows the interaction of the subgroups for representative variables associated with in-hospital mortality. In all subgroup analyses, both the disclosed and nondisclosed variables resulted with no interactions.

Table 3

Results of subgroup analyses for in-hospital mortality and length of stay

\begin{tabular}{|c|c|c|}
\hline \multirow[b]{2}{*}{ Variables } & \multicolumn{2}{|l|}{$p$ for interaction } \\
\hline & In-hospital mortality & Length of stay \\
\hline BMI & 0.339 & 0.072 \\
\hline Admission by ambulance & 0.527 & 0.298 \\
\hline Renal complication at admission & 0.068 & 0.675 \\
\hline PMX-DHP & 0.103 & 0.576 \\
\hline IRRT & 0.927 & 0.154 \\
\hline Vasopressor or inotropes within 2 days & 0.175 & 0.239 \\
\hline Mechanical ventilation within 2 days & 0.358 & 0.297 \\
\hline Hospitalization to the intensive care unit & 0.103 & 0.414 \\
\hline Academic hospital & 0.734 & 0.705 \\
\hline Malignancy as a comorbidity & 0.702 & 0.127 \\
\hline $\begin{array}{l}\text { Abbreviations: BMI, body mass index; P } \\
\text { hemoperfusion; IRRT, intermittent renal }\end{array}$ & $\begin{array}{l}\text { xin B-in } \\
\text { apy }\end{array}$ & mn-direct \\
\hline
\end{tabular}

\section{Discussion}

The present study investigated the effect of the AN69ST membrane in patients with pneumoniaassociated sepsis. As compared to CRRT with standard membranes, CRRT with AN69ST membrane reduced mortality in patients with pneumonia-associated sepsis.

Several aspects of this study that differ from those of previous studies which investigated the effect of the AN69ST membrane compared with the standard CRRT membrane[27-30]. Firstly, our previous study, which investigated the effect of the AN69ST membrane in patients with panperitonitis due to lower gastrointestinal perforation, did not show a significant difference in outcomes between the AN69ST membrane and standard CRRT membrane groups [30]. The characteristics of patients included in this 
study also differ from those of patients in the previous study. The majority of pathogenic microorganisms responsible for panperitonitis are gram-negative bacilli, which produce endotoxin [38]. On the other hand, pathogenic microorganisms causing pneumonia, particularly those that cause community-acquired pneumonia, are non-bacterial or gram-positive cocci, which do not produce endotoxins [39, 40]. The AN69ST membrane has little ability for adsorbing endotoxin [41] that facilitate cytokine production [42]. Thus, CRRT with the AN69ST membrane may not be effective for sepsis due to infections caused by gram-negative bacilli. Future research on the effectiveness of the AN69ST membrane while considering type of disease or bacterial strain is required.

Secondly, the timing of cytokine removal therapy may also have contributed to the difference between the results of previous studies and the results of this study. Several articles have reported that initiating cytokine adsorption therapy within 24 hours after diagnosis might improve patient prognosis $[43,44]$. Reports of the results of several previous studies [26-29] that investigated the effect of the AN69ST membrane did not explicitly report the timing of CRRT introduction. In this study, we only included patients in whom CRRT was initiated within 2 days of admission.

Thirdly, the severity of sepsis among patients in this study may have been lower than that in patients in previous studies. In this study, the overall in-hospital mortality rate was $38.9 \%$, and the 30 -day mortality rate was approximately $30 \%$. In contrast, the overall mortality rate was $51.4 \%$ in one study [27], and the 28-day mortality rate was $45.9 \%$ in another study [28]. It is possible that the AN69ST membrane is only effective in patients with mildly to moderately severe sepsis.

This study has several limitations. First, although we adjusted for several potential confounding factors using propensity score matching, residual confounders including laboratory results and vital signs might have biased the results. Second, because sepsis is one of the indications for CRRT with AN69ST membrane, the proportion of patients with acute kidney injury may have been smaller in the AN69ST group than in the non-AN69ST group. This may have favorably biased the results toward lower mortality rates among the patients in the AN69ST membrane group. Third, we were unable to differentiate the types of membranes used in the non-AN69ST group.

\section{Conclusion}

This retrospective cohort study suggested that use of the AN69ST membrane was significantly associated with decreased in-hospital mortality and 30-day mortality, compared to the use of standard CRRT membranes, in patients with pneumonia-associated sepsis. Other studies are needed to elucidate the clinical effectiveness of the AN69ST membrane.

\section{List Of Abbreviations}

AN69ST Acrylonitrile-co-methallyl sulfonate surface-treated CRRT Continuous renal replacement therapy 


\section{Declarations}

\section{Ethics approval and consent to participate}

The research was approved by the Institutional Review Board at The University of Tokyo (Tokyo, Japan). Patient consent was waived owing to the use of anonymized data.

\section{Consent for publication}

Not applicable

\section{Availability of data and material}

Data cannot be made publicly available for ethical reasons as the data were patient data. The data are available to interested researchers upon request to the corresponding author, pending ethical approval.

\section{Competing interests}

The authors have no conflicts of interest to declare.

\section{Funding}

This work was supported by grants from the Ministry of Health, Labour and Welfare, Japan (19AA2007 and H30-Policy-Designated-004) and the Ministry of Education, Culture, Sports, Science and Technology, Japan (17H04141).

\section{Authors' contributions}

$\mathrm{KH}, \mathrm{YS}, \mathrm{HM}, \mathrm{MN}, \mathrm{HO}, \mathrm{KF}$, and $\mathrm{HY}$ designed and conducted the research. $\mathrm{KH}, \mathrm{YS}, \mathrm{HM}, \mathrm{MN}, \mathrm{HO}$, and $\mathrm{HY}$ performed the statistical analysis and drafted the manuscript. $\mathrm{KO}$ and $\mathrm{HY}$ supervised the writing of the manuscript. All authors contributed to data interpretation, revised each draft for important intellectual content, read, and approved the final manuscript. The corresponding author $(\mathrm{KH})$ attests that all listed authors met the authorship criteria and that no other person(s) who met the criteria have been omitted.

\section{Acknowledgment}

None

\section{References}

1. Angus DC, Linde-Zwirble WT, Lidicker J, Clermont G, Carcillo J, Pinsky MR. Epidemiology of severe sepsis in the United States: analysis of incidence, outcome, and associated costs of care. Crit Care Med. 2001;29:1303-10. https://doi.org/10.1097/00003246-200107000-00002.

2. Martin GS, Mannino DM, Eaton S, Moss M. The epidemiology of sepsis in the United States from 1979 through 2000. N Engl J Med. 2003;348:1546-54. https://doi.org/10.1056/NEJMoa022139. 
3. Severiche-Bueno D, Parra-Tanoux D, Reyes LF, Waterer GW. Hot topics and current controversies in community-acquired pneumonia. Breathe. 2019;15:216-25.

https://doi.org/10.1183/20734735.0205-2019.

\section{4. $10.3410 / f .729280930 .793548187$}

Collaborators GBDLRI. (2017) Estimates of the global, regional, and national morbidity, mortality, and aetiologies of lower respiratory tract infections in 195 countries: a systematic analysis for the Global Burden of Disease Study 2015. Lancet Infect Dis. 2015;17:1133-61. https://doi.org/10.3410/f.729280930.793548187.

5. World Health Organization. Global health estimates 2016: deaths by cause, age, sex, by country and by region, 2000-2016. Geneva: World Health Organization; 2018.

6. Yende S, D'Angelo G, Kellum JA, Weissfeld L, Fine J, Welch RD, et al. Inflammatory markers at hospital discharge predict subsequent mortality after pneumonia and sepsis. Am J Respir Crit Care Med. 2008;177:1242-7. https://doi.org/10.1164/rccm.200712-17770C.

7. Menéndez R, Martínez R, Reyes S, Mensa J, Filella X, Marcos MA, et al. Biomarkers improve mortality prediction by prognostic scales in community-acquired pneumonia. Thorax. 2009;64:587-91. https://doi.org/10.1136/thx.2008.105312.

8. 10.1007/s00134-003-1662-x

Levy MM, Fink MP, Marshall JC, Abraham E, Angus D, Cook D, et al. 2001 SCCM/ESICM/ACCP/ATS/SIS international sepsis definitions conference. Crit Care Med. 2003;31:1250-6. https://doi.org/10.1007/s00134-003-1662-x.

9. Long EJ, Taylor A, Delzoppo C, Shann F, Pearson G, Buckley D, et al. A randomised controlled trial of plasma filtration in severe paediatric sepsis. Crit Care Resusc. 2013;15:198-204.

10. Ronco C, Bellomo R, Homel P, Brendolan A, Dan M, Piccinni P, et al. Effects of different doses in continuous veno-venous haemofiltration on outcomes of acute renal failure: a prospective randomised trial. Lancet. 2000;356:26-30. https://doi.org/10.1016/S0140-6736(00)02430-2.

11. Saudan P, Niederberger M, De Seigneux S, Romand J, Pugin J, Perneger T, et al. Adding a dialysis dose to continuous hemofiltration increases survival in patients with acute renal failure. Kidney Int. 2006;70:1312-7. https://doi.org/10.1038/sj.ki.5001705.

12. Villa G, Zaragoza JJ, Sharma A, Neri M, De Gaudio AR, Ronco C. Cytokine removal with high cut-off membrane: review of literature. Blood Purif. 2014;38:167-73. https://doi.org/10.1159/000369155.

13. RENAL Replacement Therapy Study Investigators. Bellomo R, Cass A, Cole L, Finfer S, Gallagher M, et al. N Engl J Med. 2009;361:1627-38. https://doi.org/10.1056/NEJMoa0902413.

14. Cruz DN, Antonelli M, Fumagalli R, Foltran F, Brienza N, Donati A, et al. Early use of polymyxin B hemoperfusion in abdominal septic shock: the EUPHAS randomized controlled trial. JAMA. 2009;301:2445-52. https://doi.org/10.1001/jama.2009.856.

15. Payen DM, Guilhot J, Launey Y, Lukaszewicz AC, Kaaki M, Veber B, et al. Early use of polymyxin B hemoperfusion in patients with septic shock due to peritonitis: a multicenter randomized control trial. Intensive Care Med. 2015;41:975-84. https://doi.org/10.1007/s00134-015-3751-z. 
16. Klein DJ, Foster D, Schorr CA, Kazempour K, Walker PM, Dellinger RP. The Euphrates trial (Evaluating the Use of polymyxin $B$ hemoperfusion in a randomized controlled trial of Adults Treated for endotoxemia and Septic Shock): study protocol for a randomized controlled trial. Trials. 2014;15:218. https://doi.org/10.1186/1745-6215-15-218.

17. Fujii T, Ganeko R, Kataoka Y, Furukawa TA, Featherstone R, Doi K, et al. Polymyxin B-immobilized hemoperfusion and mortality in critically ill adult patients with sepsis/septic shock: a systematic review with meta-analysis and trial sequential analysis. Intensive Care Med. 2018;44:167-78. https://doi.org/10.1007/s00134-017-5004-9.

18. Ronco C, Ricci Z, De Backer D, Kellum JA, Taccone FS, Joannidis M, et al. Renal replacement therapy in acute kidney injury: controversy and consensus. Crit Care. 2015;19:146. https://doi.org/10.1186/s13054-015-0850-8.

19. Angus DC, van der Poll T. Severe sepsis and septic shock. N Engl J Med. 2013;369:840-51. https://doi.org/10.1056/NEJMra1208623.

20. Doi K, Rabb H. Impact of acute kidney injury on distant organ function: recent findings and potential therapeutic targets. Kidney Int. 2016;89:555-64. https://doi.org/10.1016/j.kint.2015.11.019.

21. Oda S, Sadahiro T, Hirayama Y, Nakamura M, Watanabe E, Tateishi Y, et al. Non-renal indications for continuous renal replacement therapy: current status in Japan. Contrib Nephrol. 2010;166:47-53. https://doi.org/10.1159/000314851.

22. Yumoto M, Nishida O, Moriyama K, Shimomura Y, Nakamura T, Kuriyama N, et al. In vitro evaluation of High Mobility Group Box 1 protein removal with various membranes for continuous hemofiltration. Ther Apher Dial. 2011;15:385-93. https://doi.org/10.1111/j.1744-9987.2011.00971.x.

23. Peng Z, Pai P, Hong-Bao L, Rong L, Han-Min W, Chen $\mathrm{H}$. The impacts of continuous veno-venous hemofiltration on plasma cytokines and monocyte human leukocyte antigen-DR expression in septic patients. Cytokine. 2010;50:186-91. https://doi.org/10.1016/j.cyto.2010.02.005.

24. Chanard J, Lavaud S, Paris B, Toure F, Rieu P, Renaux JL, et al. Assessment of heparin binding to the AN69 ST hemodialysis membrane: I. preclinical studies. ASAIO J. 2005;51:342-7. https://doi.org/10.1097/01.mat.0000169119.06419.ed.

25. Désormeaux A, Moreau ME, Lepage Y, Chanard J, Adam A. The effect of electronegativity and angiotensin-converting enzyme inhibition on the kinin-forming capacity of polyacrylonitrile dialysis membranes. Biomaterials. 2008;29:1139-46. https://doi.org/10.1016/j.biomaterials.2007.11.019.

26. Shiga H, Hirasawa H, Nishida O, Oda S, Nakamura M, Mashiko K, et al. Continuous hemodiafiltration with a cytokine-adsorbing hemofilter in patients with septic shock: A preliminary report. Blood Purif. 2014;38:211-8. https://doi.org/10.1159/000369377.

27. Doi K, Iwagami M, Yoshida E, Marshall MR. Associations of polyethylenimine-coated AN69ST membrane in continuous renal replacement therapy with the intensive care outcomes: observations from a claims database from Japan. Blood Purif. 2017;44:184-92. https://doi.org/10.1159/000476052. 
28. Kobashi S, Maruhashi T, Nakamura T, Hatabayashi E, Kon A. The 28-day survival rates of two cytokine-adsorbing hemofilters for continuous renal replacement therapy: a single center retrospective comparative study. Acute Med Surg. 2019;6:60-7. https://doi.org/10.1002/ams2.382.

29. Tanaka A, Inaguma D, Nakamura T, Watanabe $Y$, Ito $E$, Kamegai $N$, et al. Effect of continuous hemodiafiltration using an AN69ST membrane in patients with sepsis. Ren Replace Ther. 2017;3:12. https://doi.org/10.1186/s41100-017-0093-z.

30. Hayashi K, Sasabuchi Y, Matsui H, Nakajima M, Ohbe H, Ono K, et al. Clinical effect of the acrylonitrile-Co-methallyl sulfonate surface-treated membrane as a cytokine adsorption therapy for sepsis due to acute panperitonitis: A retrospective cohort study. Blood Purif. 2020;49:364-71. https://doi.org/10.1159/000504560.

31. Sumitani M, Uchida K, Yasunaga H, Horiguchi H, Kusakabe Y, Matsuda S, et al. Prevalence of malignant hyperthermia and relationship with anesthetics in Japan: data from the diagnosis procedure combination database. Anesthesiology. 2011;114:84-90. https://doi.org/10.1097/ALN.0b013e318200197d.

32. Charlson ME, Pompei P, Ales KL, MacKenzie CR. A new method of classifying prognostic comorbidity in longitudinal studies: development and validation. J Chronic Dis. 1987;40:373-83. https://doi.org/10.1016/0021-9681(87)90171-8.

33. Deyo RA, Cherkin DC, Ciol MA. Adapting a clinical comorbidity index for use with ICD-9-CM administrative databases. J Clin Epidemiol. 1992;45:613-9. https://doi.org/10.1016/08954356(92)90133-8.

34. Quan H, Sundararajan V, Halfon P, Fong A, Burnand B, Luthi JC, et al. Coding algorithms for defining comorbidities in ICD-9-CM and ICD-10 administrative data. Med Care. 2005;43:1130-9. https://doi.org/10.1097/01.mlr.0000182534.19832.83.

35. Yasunaga $H$, Horiguchi $H$, Kuwabara K, Matsuda S, Fushimi $K$, Hashimoto $H$, et al. Outcomes after laparoscopic or open distal gastrectomy for early-stage gastric cancer: A propensity-matched analysis. Ann Surg. 2013;257:640-6. https://doi.org/10.1097/SLA.0b013e31826fd541.

36. Ayanian JZ, Landrum MB, Guadagnoli E, Gaccione P. Specialty of ambulatory care physicians and mortality among elderly patients after myocardial infarction. N Engl J Med. 2002;347:1678-86. https://doi.org/10.1056/NEJMsa020080.

37. Griswold ME, Localio AR, Mulrow C. Propensity score adjustment with multilevel data: setting your sites on decreasing selection bias. Ann Intern Med. 2010;152:393-5. https://doi.org/10.7326/00034819-152-6-201003160-00010.

38. Marshall JC, Innes M. Intensive Care Unit management of intra-abdominal infection. Crit Care Med. 2003;31:2228-37. https://doi.org/10.1097/01.CCM.0000087326.59341.51.

39. Mandell LA, Wunderink RG, Anzueto A, Bartlett JG, Campbell GD, Dean NC, et al. Infectious Diseases Society of America/American Thoracic Society consensus guidelines on the management of community-acquired pneumonia in adults. Clin Infect Dis. 2007;44(Suppl 2):27-72. https://doi.org/10.1086/511159. 
40. Miyashita N, Shimizu H, Ouchi K, Kawasaki K, Kawai Y, Obase Y, et al. Assessment of the usefulness of sputum Gram stain and culture for diagnosis of community-acquired pneumonia requiring hospitalization. Med Sci Monit. 2008;14:CR171-6.

41. Honore PM, Jacobs R, Joannes-Boyau O, De Regt J, De Waele E, van Gorp V, et al. Newly designed CRRT membranes for sepsis and SIRS - a pragmatic approach for bedside intensivists summarizing the more recent advances: a systematic structured review. ASAIO J. 2013;59:99-106. https://doi.org/10.1097/MAT.0b013e3182816a75.

42. Cavaillon JM. Exotoxins and endotoxins: inducers of inflammatory cytokines. Toxicon. 2018;149:45-53. https://doi.org/10.1016/j.toxicon.2017.10.016.

43. Laddomada T, Doronzio A, Balicco B. Case series of patients with severe sepsis and septic shock treated with a new extracorporeal sorbent. Crit Care. 2016;20:193.

44. Öveges N, Hawchar F, László I, Trásy D, Ondrik Z, Molnar Z. Early cytokine adsorption in septic shock (ACESS-trial): results of a proof of concept, randomized controlled pilot study. Crit Care. 2018;22(Suppl 1):82. https://doi.org/10.1016/j.jcrc.2018.11.003.

\section{Figures}




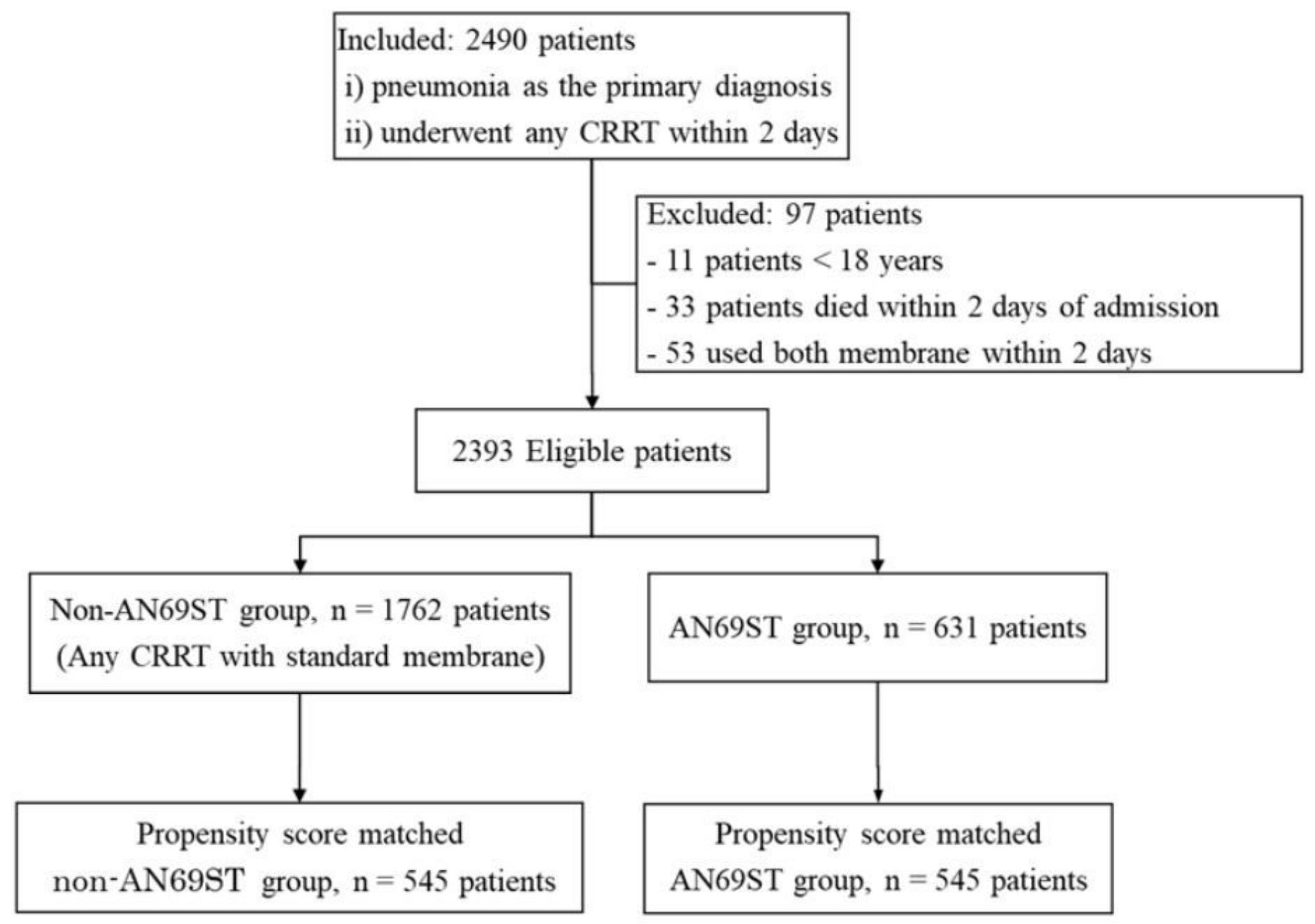

Figure 1

Flowchart for patient recruitment Abbreviations: CRRT, continuous renal replacement therapy; AN69ST, acrylonitrile-co-methallyl sulfonate surface-treated 


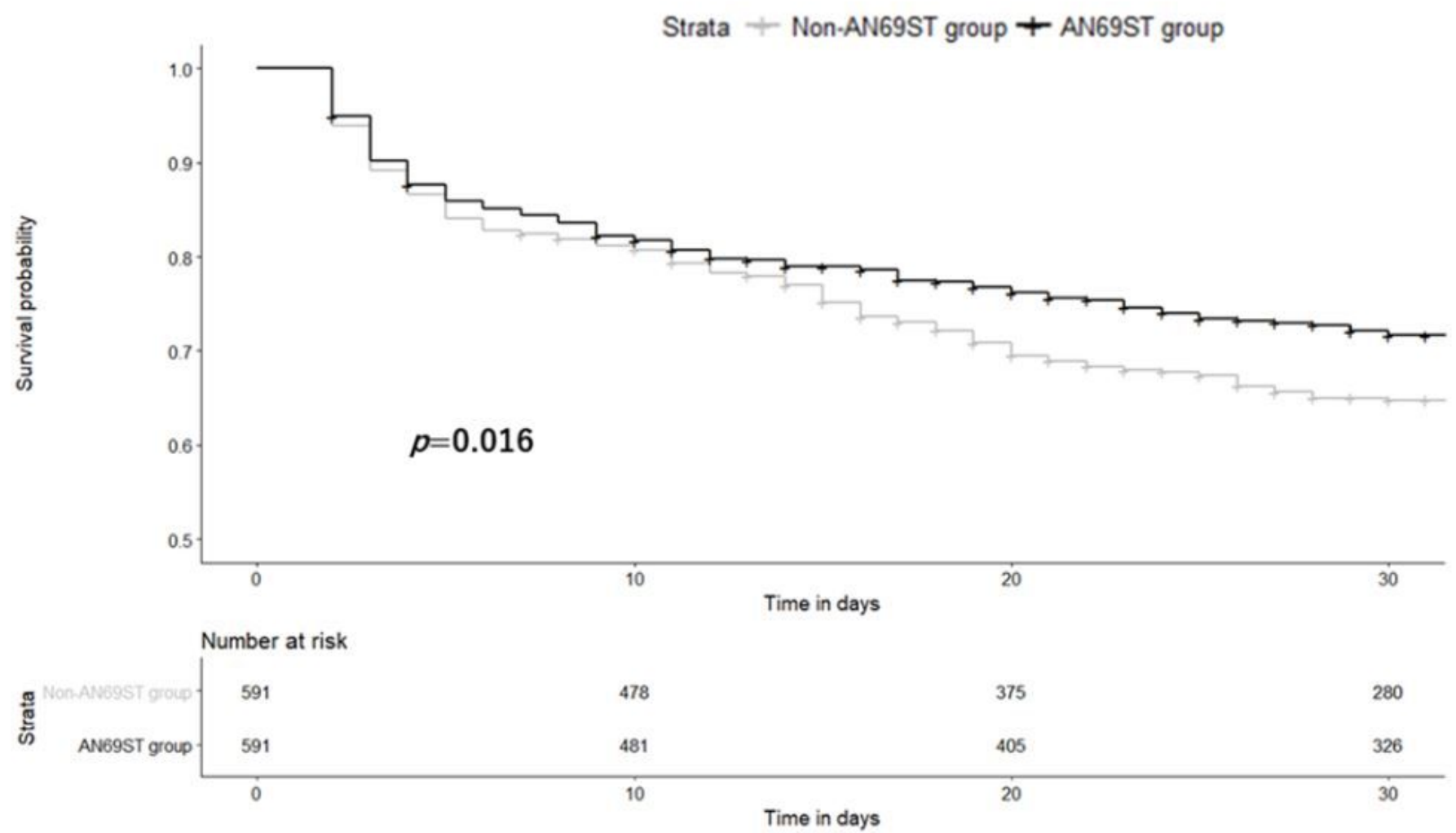

Figure 2

Kaplan-Meier survival curves Abbreviations: AN69ST, acrylonitrile-co-methallyl sulfonate surface-treated

\section{Supplementary Files}

This is a list of supplementary files associated with this preprint. Click to download.

- supplementarymaterial.pdf 